Ann. Biol. anim. Bioch. Biophys., I976, 16 (4), 537-543.

\title{
FREE AMINO ACID CONTENT OF EWE UTERINE FLUID UNDER VARIOUS HORMONAL TREATMENTS DURING EARLY PREGNANCY
}

\author{
Y. MENEZO and Suzanne WINTENBERGER-TORRES \\ Laboratoive de Biologie 406, I. N. R. A., \\ Institut national des Sciences Appliquées \\ 69621 Villeurbanne \\ Station de Physiologie animale, \\ Centre national de Recherches zootechniques, I. N. R. A., \\ 78350 Jouy en Josas
}

\section{SUMMARY}

Free amino acids are dosed in ewe uterine secretions collected by absorption on paper strips during early pregnancy (8-I 6 days p.c.). Three groups of animals were studied : control, superovulated and progesterone-treated.

As in the doe rabbit, uterine secretions are very rich in free amino acids, especially glutamic acid + glutamine and glycine. However, the glycine level drops after day 8 p.c. ; this causes a decrease in the total amount, and the best equilibrium in the relative percentage of all the different amino acids.

Hormonal treatment seems to modify the normal evolution. secretions.

Some unknown ninhydrin-positive compounds, probably peptides, are present in uterine

\section{INTRODUCTION}

Very little is known concerning nitrogen requirements of the sheep blastocyst before implantation. At that time in different species (KRISHNAN and DANIEL, I967 ; ShIRAr et al., I972 ; BeiER, I968; MENEzo, I973; RoberTs and Parker, I974) the uterus contains specific proteins which may regulate blastocyst development. It also provides a nutritive medium reflecting blastocyst needs. In rabbit, the maximum 
concentration of free amino acids in the uterine lumen coincides with the presence of the unattached blastocyst (JASZCZAK et al., I972), which imperatively neads an amino nitrogen source for further development (BRINSTER, I970). Our purpose was to determine if such a phenomenon occurs in ewe because it might be related to an increase in the rate of blastocyst development at 8 days p.c. The effect of progesterone and superovulation on uterine fluid is also studied, as it has been shown that hormonal treatment has a favourable effect on embryonic growth (WINTENBERGER-TORRES, I964). However, as the composition of uterine fluids seems to depend greatly on collection technique (WALES and RESTALL, I97I ; WALES, I973), we used the one described by JASZCZAK and HAFEZ (I972) ; there is no cannulation but uterine fluids of freshly killed animals are absorbed on paper strips.

\section{MATERIAL AND METHODS}

For each group, 9 Préalpes ewes of proven fertility were used (3 animals for each date).

- The superovulated group received a subcutaneous injection of 2 ooo IU of PMSG on day $13 \mathrm{I} / 2$ of the preceding cycle; ewes were killed 8,12 and 16 days after mating;

- In the progesterone group, animals received a daily subcutaneous injection of $40 \mathrm{mg}$ of progesterone from day 3 to the day of slaughter;

- The control group received no treatment.

All animals were fed in the same conditions.

To collect uterine fluids, animals were killed and the uteri opened. The secretion was then absorbed on strips of paper of well-defined weight (Whatman I). The amount of fluid absorbed was determined by the difference in weight before and after absorption. The strips were then frozen until analyzed. The corpus luteum and the embryo were weighed to determine their quality.

Free amino acids were extracted with $82^{\circ}$ ethanol, according to PAWLAcK and Pron (r968) using internal labelling (norleucine and $\alpha$-amino $\beta$-guanido propionic acid). One was used for analysis by ion exchange chromatography on an Optica aminolyzer (SPACKMAN et al., I958; MondiNo, 1967 ; NoE et al., 1974) ; the other was hydrolyzed (HCl 6N, 24 hours under nitrogen atmosphere) to determine if any unknown peaks were due to soluble peptides, and free amino acid level increase resulted from hydrolysis of these peptides.

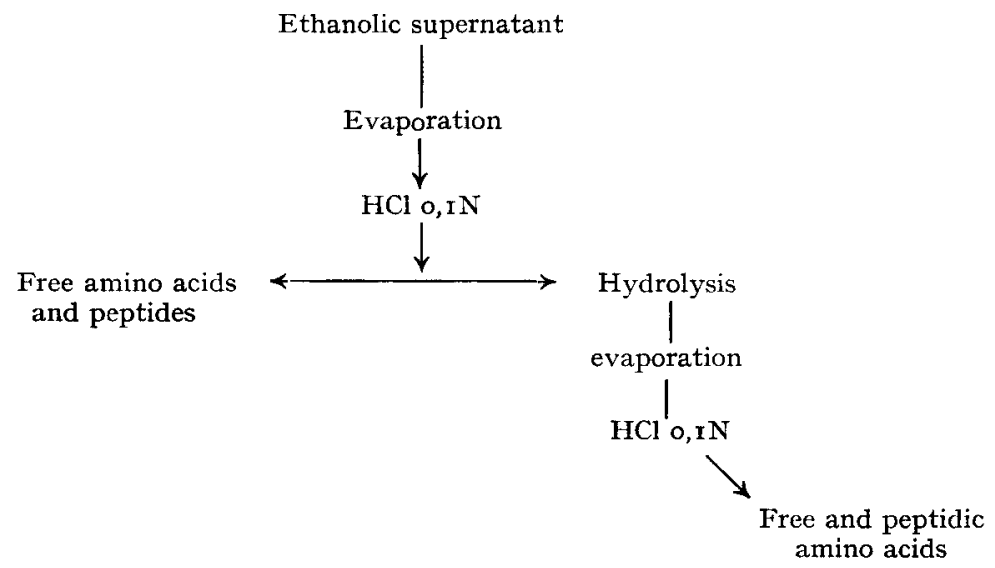

Virgin strips of paper were examined for the presence of free amino acids and peptides. 
RESULTS (tables I and 2, fig I)

Uterine fluid is a very rich medium. However, the high free amino acid level is due to an exceptional amount of glycine and to lower amounts of glutamic acid and glutamine, especially at 8 and I2 days p.c. Taurine, aspartic acid and asparagine, alanine, the leucines, valine and lysine are also represented. FAHning et al. (1967) studying cow and JASCZAK and HAFEZ (1972) studying doe observed nearly the same spectrum.

TABLE I

Concentration $(\mu \mathrm{g} / \mathrm{g})$ of ninhidrine positive compounds of uterus secretions post coitum

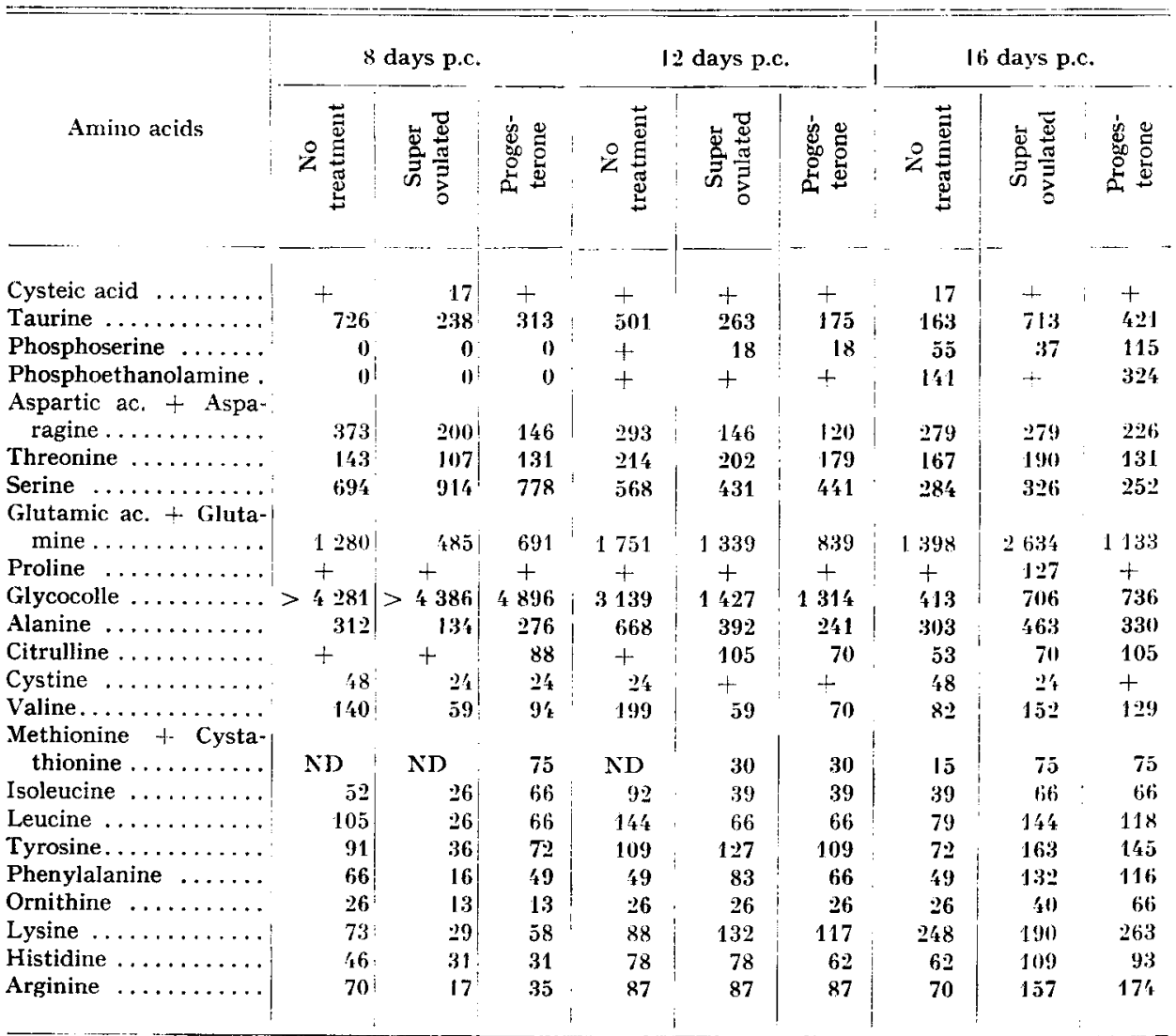

ND : not determinated.

+ : traces. 


\begin{tabular}{|c|c|c|c|c|c|c|c|c|c|}
\hline \multirow[b]{2}{*}{ Amino acids } & \multicolumn{3}{|c|}{8 days p.c. } & \multicolumn{3}{|c|}{12 days p.c. } & \multicolumn{3}{|c|}{16 days p.c. } \\
\hline & 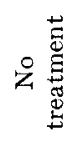 & 总 & 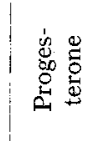 & 学莺 & 总总 & 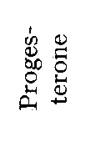 & 乙 & 奇兽 &  \\
\hline Cysteic acid ... & & 0,24 & & & & & 0,42 & & \\
\hline Taurine $\ldots \ldots \ldots$ & 8,33 & 3,33 & 3,96 & 5,41 & 5,21 & 4,30 & 4,01 & 10,49 & 8,47 \\
\hline Phosphoserine $\ldots \ldots$ ' & & & & & 0,36 & $0,4^{\prime} \mathbf{x}$ & 1,35 & 0,54 & 2,21 \\
\hline Phospho-ethanolamine & & & & & & & 3,47 & & 6,46 \\
\hline $\begin{array}{c}\text { Aspartic ac. }+ \text { Aspa- } \\
\text { ragine } \ldots \ldots \ldots \ldots\end{array}$ & 4,28 & 2,80 & 1,85 & 3,17 & 9,89 & 2,95 & 6,87 & 4,10 & 4,50 \\
\hline Threonine $\ldots \ldots \ldots \ldots$ & 1,64 & 1,50 & 1,66 & 2,31 & 4,00 & 4,40 & 4,11 & 2,80 & 2,61 \\
\hline Serine $\ldots \ldots \ldots \ldots$ & 7,96 & 12,79 & 9,85 & 6,14 & 8,53 & $10,8^{\prime}+$ & 6,99 & 4,80 & 5,02 \\
\hline $\begin{array}{r}\text { Glutamic ac. }+ \text { Gluta- } \\
\operatorname{mine} \ldots \ldots \ldots \ldots \\
\text { Proline } \ldots \ldots \ldots \ldots\end{array}$ & 14,68 & 6,79 & 8,74 & 29,73 & 26,51 & 20,62 & 34,41 & $\begin{array}{r}38,75 \\
1,87\end{array}$ & 22,58 \\
\hline Glycine. . . . . . . . . & 49,09 & 61,38 & 61,96 & 33,92 & 28,26 & 32,29 & 10,16 & 10,39 & 14,67 \\
\hline Alanine $\ldots \ldots \ldots \ldots$ & 3,58 & 1,88 & 3,49 & 7,22 & 7,76 & 5,92 & 7,46 & 6,81 & 6,58 \\
\hline $\begin{array}{c}\text { Citrulline }+ \text { acid } \alpha \text { ami }- \\
\text { no butyrique } \ldots \ldots\end{array}$ & & & 1,11 & & 2,08 & 1,72 & 1,30 & 1,03 & 2,09 \\
\hline Cystine $\ldots \ldots \ldots \ldots$ & 0,55 & 0,34 & 0,30 & 0,26 & + & & 1,18 & 0,35 & \\
\hline Valine........... & 1,61 & 0,83 & 1,19 & 2,15 & 1,17 & 1,72 & 2,02 & 2,24 & 2,57 \\
\hline Methionine ..... & 2,22 & 5,43 & 0,95 & 2,42 & 0,59 & 0,74 & 0,37 & 1,10 & 1,49 \\
\hline Isoleucine $\ldots \ldots \ldots \ldots$ & 0,60 & 0,36 & 0,84 & 0,99 & 0,77 & 0,96 & 0,96 & 0,97 & 1,32 \\
\hline Leucine . . . . . . . . & 1,20 & 0,36 & 0,84 & 1,56 & 1,31 & 1,62 & $1,9 \prime$ & 2,12 & 2,35 \\
\hline Tyrosine ........... & 1,04 & 0,50 & 0,91 & 1,18 & 2,51 & 2,68 & 1,77 & 2,40 & 2,89 \\
\hline Phenylalanine . . & 0,76 & 0,22 & 0,62 & 0,53 & 1,64 & 1,62 & 1,21 & $1,9 t$ & 2,31 \\
\hline Ornithine $\ldots$. & 0,30 & 0,18 & 0,16 & 0,28 & 0,51 & 0,64 & 0,64 & 0,59 & 1,32 \\
\hline Lysine $\ldots \ldots \ldots \ldots$ & $0,8^{\prime}$ & 0,40 & 0,73 & 0,95 & 2,61 & 2,88 & 6,10 & $\stackrel{9}{2} 80$ & 5,24 \\
\hline Histidine $\ldots \ldots \ldots \ldots$ & 0,53 & 0,43 & 0,39 & 0,84 & 1,54 & 1,52 & 1,53 & 1,60 & 1,85 \\
\hline Arginine $\ldots \ldots \ldots \ldots$ & 0,80 & 0,24 & 0,44 & 0,94 & 1,72 & 2,14 & 1,72 & 2,31 & 3,47 \\
\hline
\end{tabular}

If we consider the advancement of pregnancy, some observations can be made :

- there is a drastic decrease in the total amount of the free amino acids between day 8 and day I2, mostly due to a drop in glycine and serine;

-- on the other hand, the relative percentage of numerous animo acids, such as leucine, arginine, alanine, tyrosine, phenylalanine, taurine, glutamic acid and glutamine, 1ysine, increases,

- phosphoethanolamine and phosphoserine are present only at 12 days p.c. ; they increase at $\mathrm{I} 6$ days p.c. in all groups.

Two different hormonal treatments for the same p.c. dates do not seem to play an important role in different amino acid levels, except on day 12 p.c., where the treatments cause a decrease in the level of numerous amino acids. This level is then stable until i6 days p.c., when the level of the control group drops.

At least six unknown peaks of ninhydrin-positive compounds can be detected. 




There is one between taurine and aspartic acid, one just before aspartic acid, one between aspartic acid and threonine, one between glutamine and proline, one close to valine, and the last between cystine and methionine. These compounds are present in all groups, but they disappear after hydrochloric hydrolysis and provoke an increase in numerous amino acid levels. This suggests strongly that these unknown compounds are peptides. Aspartic acid and glutamic acid (including asparagine and glutamine, glycine and the leucines) increase about $50 \mathrm{p}$. $\mathrm{r}$ oo. Phenylalanine, lysine, histidine and arginine increase even more and may double after hydrolysis of the ethanolic supernatant. It is difficult to determine the increase of cystine, as in the ethanolic extract before hydrolysis, because it is very scarce. However, it is reasonable to suppose that one of the unknown compounds detected close to aspartic acid is glutathion. 


\title{
DISCUSSION AND CONCLUSION
}

As observed for the rabbit (JASzCZAK and HAFEZ, I972; IRITANI et al., I97I), the total concentration of free amino acids in the ewe is higher using absorption on paper strips than using a cannulation technic (WALES, I973; MENEZO, I973). This can be explained either by a more important evaporation when using paper strips or by a modification of water transfer due to the cannula.

However, for these two species and also for the cow (FAHNING et al., I967) free aminoacid level, under progesterone influence, is several times higher in uterine fluid than in serum. The relative proportions of the different amino acids and their variations are quite similar, with high levels of glycine and taurine.

A comparison with the levels observed at oestrus shows clearly that uterine secretion is active and under hormonal control.

The significance of such high quantities of amino nitrogen compounds is not known. Even if glycine and many other compounds can pass through the blastocoelic wall, it is difficult to believe that it is all used for embryo building material. However, the free glycine level in the uterus decreases after 8 days p.c. when the embryonic need for nuclear material synthesis (purine) and protein synthesis is important.

The roles of phosphoserine and phosphoethanolamine are also interesting. They have been detected in the blastocoelic fluid of rabbit (JASzczAK and al., I972) and so may be the metabolic intermediates of first phospholipid synthesis.

The possible role of the peptides detected is mysterious. It is probable that some unknown compounds described by JASzczAK and HAFEZ (I972) in doe were also due to peptides. They possibly pass through the blastocyst membrane as blastokinin does (PETZOL,DT, I974). They may result from an enzymatic degradation of uterine secretions or from biosynthesis in utero. However, according to their molecular weight they could also play a role in luteolysis prevention.

If we consider the hormonal treatments in vivo, injections of progesterone and the presence of numerous corpora lutea have the same effects. Especially for I2 days p.c., they induce inversion of the normal evolution, and mean ratio values for nearly all the amino acids differ from the control gray. These observations may be correlated with an acceleration of embryonic growth between day 8 and day 12 , and the high embryonic mortality at I6 days p.c.

Reçu pour publication en septembre $19 \pi 5$.

\author{
RÉSUMÉ \\ AMINOACIDES LIBRES DC LIQUIDE UTÉRIN DE BREBIS \\ SOUMISE A DIVERS TRAITEMENTS HORMONAUX \\ EN DÉBUT DE GESTATION
}

\footnotetext{
Les acides aminés libres sont dosés sur les sécrétions utérines de Brebis, collectées par absorption sur papier au début de la gestation (8-16 jours p.c.). Trois groupes d'animaux ont été étudiés : témoins, superovulés et traités à la progestérone.
} 
Comme chez la Lapine, les sécrétions utérines sont très riches en aminoacides, notamment acide glutamique + glutamine et surtout glycine. Ce composé chute cependant après le $8^{e}$ jour post coïtum, entraînant une diminution de la teneur totale en aminoacides et un meilleur équilibre dans le pourcentage relatif des autres composés. Les traitements hormonaux tendent à inverser l'évolution normale.

Enfin, des composés ninhydrine positifs inconnus, probablement des peptides, sont présents dans les sécrétions utérines.

\section{REFERENCES}

Beier M. M., I368. Uteroglobin : a hormone sensitive endometrial protein involved in blastocyst development. Biochim. biophys. Acta, 160, 289-29I.

Brinster R. L., i97o. In Gibian H., Plotz E. S. Mammalian Reproduction, Springer, 229.

Fahning M. L., Schultz R. H., Graham E. F., 1967. The free amino acid content of uterine fluids and blood serum in the cow. J. Reprod. Fert., 13, 229-236.

IrItani A., Nishikawa Y., Gomes W. R., VAndemark N. L., I97r. Secretion rates and chemical composition of oviduct and uterine fluids in rabbits. J. Anim. Sci., 38, 829-835.

Jaszczak S., Benty K., Choroszewska A., r972. Concentration of $\alpha$-amino nitrogen and free amino acid in the uterine and blastocoelic fluid of rabbit. Acta Eur. Fert., 3, 183-191.

Jaszczak S., Hafez E. S. E., I972. Endocrine control of free amino acid content in uterine fluid in pregnant rabbits. Acta endocr., 70, 409-4I6.

Krisinan R. S., Daniel J, C., r967. "Blasíokinin": Inducer and regulative of blastocyst development in the rabbit uterus. Science, $158,490-493$.

Menezo Y., I973. Étude électrophorétique des protéines des sécrétions utérines de brebis au début de la gestation. C. R. Acad. Sci. Paris, D, 277, 337-340.

Menezo Y., r973. Les composés azotés des sécrétions tubaires et utérines chez la brebis en œstrus. Comparaison avec le liquide séminal et le plasma sanguin. In Speym transport, survival cind fertilizing ability, 26, 389-406, I.N.S.E.R.M. éd. Paris.

Mondino A., 1967. A new system for automatic amino acid analysis. J. Chromatography, 30, Ioo-I I2.

Noe V., Menezo Y., Bonnot G., 1974. Separazione di aminoacidi basici con taniponi al sodio su resina scambio ionica. Riv. Soc. Ital. Sc. Alimentizione, 6, 171-173.

Pawlack M., Pion R., I968. Influence de la supplémentation des protéines du blé par des doses croissantes de lysine sur la teneur en acides aminés libres du sang et du muscle de Rat en croissance. Ann. biol. anim. Bioch., Biophys., 8, 5I7-530.

Petzold U., I974. Microdisc electrophoresis of soluble proteins in rabbit blastocysts. $\int$. Embryol. exp. Morph., 31, 479-487.

Roberts G. P., PARKer J. M., I974. Macromolecular romponents of the luminal fluid from the bovine uterus. J. Reprod. Fert., 40, $29 \mathrm{x}-303$.

Shirai E., Lisuka R., Notake E., 1972. Analysis of human uterine fluid proteins. Fert. Steril., 23, $522-528$.

Spackman D. M., Stein W. H., Moore S., 1958. Automatic recording apparatus for use on the chromatography of amino acids. Anal. Chem., 82, I $190-1206$.

Walfs R. G., Restall B. J., I97I. The uterus of the ewe. I. Secretion from the cannulated uterus. A ust. J. Biol. Sci., 24, 1009-102I.

Walfs R. G., I973. The uterus of the ewe. III. Chemical analysis of uterine fluid collected by caniulation. A ust. J. Biol. Sci., 26, 961-969.

Wintenberger-Torres S., I964. Infuence de l'équilibre hormonal sur la vitesse de segmentation des oufs de brebis. C. R. Acad. Sci. Paris, 259, 1660-1662. 